\title{
CERIA-BASED MATERIALS FOR HIGH-TEMPERATURE ELECTROCHEMISTRY APPLICATIONS
}

\author{
E. YU. PIKALOVA ${ }^{1,2}$, A.A. KOLCHUGIN ${ }^{1}$ \& V.G. BAMBUROV ${ }^{2,3}$ \\ ${ }^{1}$ Institute of High Temperature Electrochemistry, UB RAS, Russia. \\ ${ }^{2}$ Department of Environmental Economics, Ural Federal University, Russia. \\ ${ }^{3}$ Institute of Solid State Chemistry, UB RAS, Russia.
}

\begin{abstract}
This paper describes the experimental studies of multi-component solid state electrolytes based on $\mathrm{CeO}_{2}$ and their application in intermediate temperature electrochemical devices. Two important aspects are emphasized: the effect of different dopants' ionic radius and concentration on the electrical properties of $\mathrm{CeO}_{2}$-based solid solutions in air and the influence of combined dopants on the electrolytic properties of solid electrolytes from the standpoint of the critical oxygen partial pressure $\mathrm{pO}_{2}$ at which point the values of the electronic and ionic components of conductivity are equal. Examples of usage of the developed multi-component $\mathrm{Ce}_{0.8}\left(\mathrm{Sm}_{0.75} \mathrm{Sr}_{0.2} \mathrm{Ba}_{0.05}\right)_{0.2} \mathrm{O}_{2-\delta}$ electrolyte synthesized by solid state, laser evaporation and combustion methods and composites on the base of $\mathrm{Ce}_{0.8}\left(\mathrm{Sm}_{0.8} \mathrm{Sr}_{0.2}\right)_{0.2} \mathrm{O}_{2-\delta}$ electrolyte as a component of electrochemical devices such as solid oxide fuel cell, gas sensors and as a component of the mixed ionic and electronic conducting (MIEC) membranes for hydrogen and syngas gas production are cited.

Keywords: $\mathrm{CeO}_{2}$, electrolytic domain boundary, energy production, hydrogen production, MIEC membranes, oxygen conductivity, potentiometric gas sensor, SOFC, solid-state electrolytes
\end{abstract}

\section{INTRODUCTION}

Oxygen ion conductors are of special interest due to their use in many applications such as oxygen sensors, electrochemical pumps and solid oxide fuel cells (SOFCs). In the ongoing search for alternative and environmental-friendly power generation facilities, SOFCs have generated much interest as a potentially economical, clean and efficient candidate for the decentralized generation of heat and power [1-3]. Government funding for fuel cells has fluctuated over the years but the total spent by Japan, USA and Europe between 1995 and 2013 was $\$ 8.3$ billion [4]. Within the framework of the Federal Target Program 'Research and development in areas of high priority for the scientific-technological complex of Russia for 2007-2012' and the Federal Target Program 'National Technological Base' for 2007-2011 hundreds of millions of rubles have been directed to these tasks in Russia. Under the Skolkovo Fund program in the area of power-efficient technologies, two big projects connected with the development of SOFC-based mini power plants (from 0.5 to $25 \mathrm{~kW}$ output capacities) were announced and carried out from 2013 to 2015 [5]. At present, however, the techno-economic potential of SOFC technology faces two major critical issues, i.e. the development of a low-cost production process for the cell components and their inadequate durability. The current approach to reducing an SOFC's operating temperature is focused on a wider choice of low-cost materials, particularly for the interconnectors (including metallic) and the sealant, a longer cell life time due to reduced inter-diffusion between the stack components, improved reliability and reduced overall cost. The most commonly used electrolyte, yttria stabilized zirconia (YSZ), exhibits sufficient ionic conductivity at $\sim 1000^{\circ} \mathrm{C}$ and is characterized by good thermal stability. Alternatively, ceria solid solutions exhibit 4-5 times greater ionic conductivity values across the intermediate temperature range [6]. This property has attracted great interest from the scientific community concerning the investigation into 
and the use of ceria as an electrolytic material not only for intermediate temperature SOFCs but also for other electrochemical applications [7-9].

The history of the development of ceria-based materials in Russia is a rich one, but up until now investigation has centered mainly on the single-doped ceria solid-state solutions [10]. The main disadvantage of ceria-based electrolytes, which cannot be resolved by single doping, is the appearance of electronic conductivity at low oxygen partial pressures due to $\mathrm{Ce}^{4+}$ being partially reduced to $\mathrm{Ce}^{3+}$, which causes a partial internal electronic short circuit in an SOFC decreasing its performance and an expansion of the lattice leading to mechanical failure of the cell during exploitation [6]. Some effort has been made to suppress the electronic conductivity and to extend the electrolyte domain of the ceria-based electrolytes through the structural modification of ceria-based solid solutions by co-doping with two or more dopants [11-13]. These works have influenced our scientific group to study the $\mathrm{CeO}_{2}$-based multi-component solid-state electrolytes from the perspective of their future application in electrochemical devices. The study had two main areas of focus: clarification of the effect of different dopants' ionic radius with emphasis on the electrical properties of $\mathrm{CeO}_{2}$-based solid solutions in air and the investigation of the influence of combined dopants on the electrolytic properties of solid electrolytes across a wide range of oxygen partial pressure. The new technology for nanoscale powder production developed at the Institute of Electrophysics UB RAS for the single-doped $\mathrm{ZrO}_{2}$ and $\mathrm{CeO}_{2}$ [14] was applied to the multi-component electrolytes. It was shown that developed multi-component electrolytes $\mathrm{Ce}_{0.8}\left(\mathrm{Sm}_{0.8} \mathrm{Sr}_{0.2}\right)_{0.2} \mathrm{O}_{2-\delta}$ and $\mathrm{Ce}_{0.8}\left(\mathrm{Sm}_{0.75} \mathrm{Sr}_{0.2} \mathrm{Ba}_{0.05}\right)_{0.2} \mathrm{O}_{2-\delta}$ can be used not only in SOFCs but also as a base for potentiometric gas sensors and as a component of the mixed ionic and electronic conducting membranes for hydrogen and syngas production.

\section{EXPERIMENTAL}

\subsection{The preparation procedure and powder characterization}

The solid-state composition $\mathrm{Ce}_{1-\mathrm{x}}\left(\mathrm{Ln}_{0.5} \mathrm{Ln}_{0.5}^{\prime}\right)_{\mathrm{x}} \mathrm{O}_{2-\delta}\left(\mathrm{x}=0-0.20 ; \mathrm{Ln}=\mathrm{Sm}, \mathrm{La}, \mathrm{Gd}\right.$ and $\mathrm{Ln}^{\prime}=$ $\mathrm{Dy}, \mathrm{Nd}, \mathrm{Y})$ and some systems with simultaneous doping by rare-earth and alkali-earth elements $\mathrm{Ce}_{0.8}\left(\mathrm{Sm}_{1-\mathrm{x}} \mathrm{M}_{\mathrm{x}}\right)_{0.2} \mathrm{O}_{2-\delta}(\mathrm{M}=\mathrm{Ca}, \mathrm{Sr}, \mathrm{x}=0.0-1.0)$ and $\mathrm{Ce}_{0.8}\left(\mathrm{Sm}_{1-\mathrm{x}-\mathrm{y}} \mathrm{Ba}_{\mathrm{y}} \mathrm{M}_{\mathrm{x}}\right)_{0.2} \mathrm{O}_{2-\delta}$ $(\mathrm{M}=\mathrm{Ca}, \mathrm{Sr} ; \mathrm{x}=0,0.15,0.20 ; \mathrm{y}=0.05,0.1)$ were synthesized by the application of three different techniques: solid-state reaction, laser-induced evaporation of solid-state target (Laser powders) and the glycine-nitrate method, described in detail in [15].The calcination temperatures varied from 600 to $1150^{\circ} \mathrm{C}$ depending on the procedure.

The specific surface areas of the obtained powders were tested by the surface area and porosity analyzer TriStar 3000 V6.03 A. The content of metal oxides in the starting materials and solid-state composition, obtained by different methods, was defined by a Plasma Emission Spectrometer Optima 4300DV (USA). The X-ray diffraction (XRD) technique was employed to identify the phases and to obtain the values of the lattice constants. The XRD analysis was performed on the milled powders of specimens using a D/MAX-2200 (Rigaku Co. Ltd, Japan) diffractometer with Ni-filtered $\mathrm{Cu}-\mathrm{K}_{\alpha}$ radiation in the range of $10^{\circ} \leq 2 \theta \leq 85^{\circ}$.

\subsection{The preparation and characterization of compact ceramic samples}

Powders prepared by different procedures were compacted by the magnetic pulse technique developed at the Institute of Electrophysics UB RAS [16] into disks with a diameter of $30 \mathrm{~mm}$ (pulsed pressure $300 \mathrm{MPa}$ in amplitude and $100 \mathrm{mks}$ in duration) and into bars $5 \times 25 \times 1 \mathrm{~mm}$ 
sintered in air in an electric furnace with controlled heating (heating/cooling rate $5^{\circ} \mathrm{C} / \mathrm{min}$ and a maximal temperature of $1600^{\circ} \mathrm{C}$ with a soaking time $3 \mathrm{~h}$ ). The densities of the samples were determined by hydrostatic weighing in water. The grain size and their distribution on the surface of the sintered ceramic samples were controlled by a raster electronic microscope JSM-5500 LV JEOL (Japan).

The electrical conductivity measurements were carried out on the bar-shaped samples by employing the four-point DC technique using a home-made electrochemical experimental set (Fig. 1a). The sample (4) was installed in a tube made of $\mathrm{ZrO}_{2}$-based electrolyte (1). Platinum paste stripes deposited on the inner and outer surfaces of the tube and connected with platinum wires were used as the electrochemical oxygen pump (2) and the electrochemical sensor (3). Four Pt electrodes (current (5) and measuring (6)) were deposited on the surface of the samples and connected with Pt wires. Temperature and oxygen partial pressure were varied automatically by means of the microprocessor system Zirkonia-318 across the range of $600-900^{\circ} \mathrm{C}$ and $0.21-10^{-25}$ atm, respectively.

Electrochemical characterization was performed on the 0.8-mm-thick disk-shaped electrolyte samples with Pt symmetric electrodes $\left(\mathrm{S}=0.78 \mathrm{~cm}^{2}\right.$ and $\left.30 \mathrm{mg} / \mathrm{cm}^{2}\right)$, which were painted and sintered on both sides of the disks at $1000^{\circ} \mathrm{C}, 1 \mathrm{~h}$ and activated with praseodymium nitrate to lower the polarization resistance [17]. The schema of the experimental set is presented in Fig. 1b. A disk-shaped sample (2) was pressed under a spring load (1) onto the end face of a tube made of $\mathrm{ZrO}_{2}$-based electrolyte (8). Wet hydrogen $\left(98 \% \mathrm{H}_{2}+2 \% \mathrm{H}_{2} \mathrm{O}, \mathrm{V}_{\mathrm{H} 2} \sim\right.$ 2-5 1 per hour) was fed to the anode through the central tube. The oxygen partial pressure in the anode channel was set using the electrochemical pump (7) and controlled by the sensor (6). The cathode volume was blown through with air $(\mathrm{V} \sim 6-15 \mathrm{l} / \mathrm{h})$. The cell temperature was measured by the Pt-Pt/Rh thermocouple, which was placed near the sample (5). The overvoltage of the electrodes and the ohmic voltage drop in the electrolyte were determined under stationary conditions (galvanostatic mode) by the current interruption method. The length of the current interruption edge did not exceed $0.3 \mu \mathrm{s}$. The off-current state of the cell during a period was $\tau_{\text {off }} \sim 0.3 \mathrm{~ms}$. The relative duration of the cut-off pulses was $\tau_{\text {off }} / \tau_{\text {on }} \leq 1 / 1540$.

\subsection{Tubular elements for electrochemical applications}

Tube-shaped membranes $120-200 \mathrm{~mm}$ in length, $12 \mathrm{~mm}$ in diameter and $0.5-0.65 \mathrm{~mm}$ in thickness were fabricated from the electrolyte of composite material (50:50 mixture of the

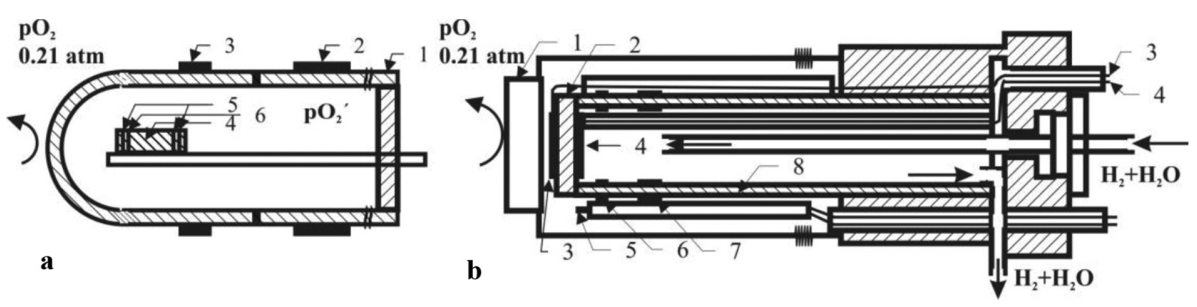

Figure 1: (a) Measuring cell for the four-probe measurements in the controlled environment: (1) YSZ ceramic tube; (2) electrochemical pump; (3) electrochemical sensor; (4) sample; (5) current electrodes; (6) measuring electrodes. (b) Measuring cell for the electrochemical characterization: (1) spring load; (2) sample; (3) cathode; (4) anode; (5) thermocouple Pt-electrodes of (6) electrochemical sensor and electrochemical pump (7) deposited on YSZ ceramic tube (8). 
$\mathrm{CeO}_{2}$-based electrolyte as an ionic conductor and $\mathrm{SrTi}_{0.5} \mathrm{Fe}_{0.5} \mathrm{O}_{3-\delta}$ as an mixed ionic and electronic conducting, MIEC) utilizing the tape rolling (calendering) method (Fig. 2). For the first stage the organic binder (caoutchouc nitrile-butadiene dissolved in a mixture of acetone and gasoline) and plasticizer (dibutyl phthalate) were added to the ceramic powder and thoroughly mixed in the planetary mill. The resulting mixture was poured onto a fluoroplastic substrate and dried in the open air. For the second stage, the dried mass was rolled by a Durston rolling machine (UK) into films with a thickness of $0.6 \mathrm{~mm}$ and then immediately laid over a metal rod to form a tubular shape. Green tubes were held in an air atmosphere for a period of $24 \mathrm{~h}$ and then sintered in the special supported form at $1420-1550^{\circ} \mathrm{C}$ for $3 \mathrm{~h}$ with a heating/cooling rate of $0.5^{\circ} \mathrm{C} / \mathrm{min}$. The same procedure was applied to two-layered tube elements where one film was prepared with the addition of pore former (starch in amount 15-30 wt.\%) and the other without it. They were then co-rolled together. These can be used for anode-supported SOFCs and two-layered electrochemical convertors for hydrogen and synthesis gas production.

\section{RESULTS AND DISCUSSION}

\subsection{Structural properties}

The XRD analysis revealed that all the synthesized $\mathrm{Ce}_{1 \mathrm{x}}\left(\operatorname{Ln}_{0.5} \operatorname{Ln}_{0.5}^{\prime}\right)_{\mathrm{x}} \mathrm{O}_{2-\delta}(\mathrm{x}=0-0.20$; $\mathrm{Ln}=\mathrm{Sm}, \mathrm{La}, \mathrm{Gd}$ and $\left.\mathrm{Ln}^{\prime}=\mathrm{Dy}, \mathrm{Nd}, \mathrm{Y}\right)$ compositions were single phase with a cubic fluorite structure (e.g. Fm3m) (Fig. $3 \mathrm{a}$ and Table 1). The compositions $\mathrm{Ce}_{0.8}\left(\mathrm{Sm}_{1-\mathrm{x}} \mathrm{M}_{\mathrm{x}}\right)_{0.2} \mathrm{O}_{2-\delta}(\mathrm{M}=\mathrm{Ca}$, $\mathrm{Sr} ; \mathrm{x}=0.0-1.0)$ with $\mathrm{Ca}^{2+}$ were single phase throughout the full range of compositions (Table 2), while the solubility limit of $\mathrm{Sr}^{2+}$ was approximately $8 \mathrm{~mol} . \%$, at $\mathrm{x}>0.4$, the second phase $\mathrm{SrCeO}_{3}$ was identified (Fig. 3b). The XRD analysis of the compositions $\mathrm{Ce}_{0.8}\left(\mathrm{Sm}_{1-\mathrm{x}-\mathrm{y}}\right.$ $\left.\mathrm{Ba}_{\mathrm{y}} \mathrm{M}_{\mathrm{x}}\right)_{0.2} \mathrm{O}_{2-\delta}(\mathrm{M}=\mathrm{Ca}, \mathrm{Sr} ; \mathrm{x}=0,0.15,0.20 ; \mathrm{y}=0.05,0.1)$ revealed fluorite structure without second phases; however, the electron microscopy scanning showed the appearance of second phases in the triple points. An average bulk-surface effective diameter of particles $d_{\mathrm{BET}}$ was calculated from the specific surface area of powders $S_{\mathrm{BET}}$, which was approximately $1.5-2$, 20-25 and 40-45 $\mathrm{m}^{2} / \mathrm{g}$ for Solid, Chem and Laser powders, respectively.

In the case of Laser powders, there was close concurrence in crystallite size, calculated from XRD data and $d_{\mathrm{BET}}$, because they were not agglomerated, having mainly sphericalshaped particles [15]. Chem powders were agglomerated; however, the micro-sized agglomerates were spongy so the specific surface area increased, more than in the case of Solid powders, which were strongly agglomerated and the procedure of their milling for some
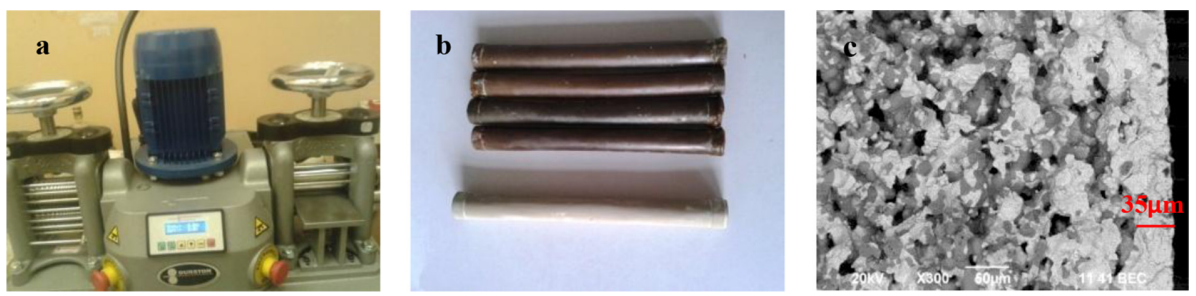

Figure 2: Calendering procedure: (a) Durston rolling machine; (b) electrolyte green and sintered tubes, (c) an example of two-layered porous anode support $(0.5 \mathrm{~mm})-$ gas-tight electrolyte (about $35 \mu \mathrm{m}$ ) structure. 

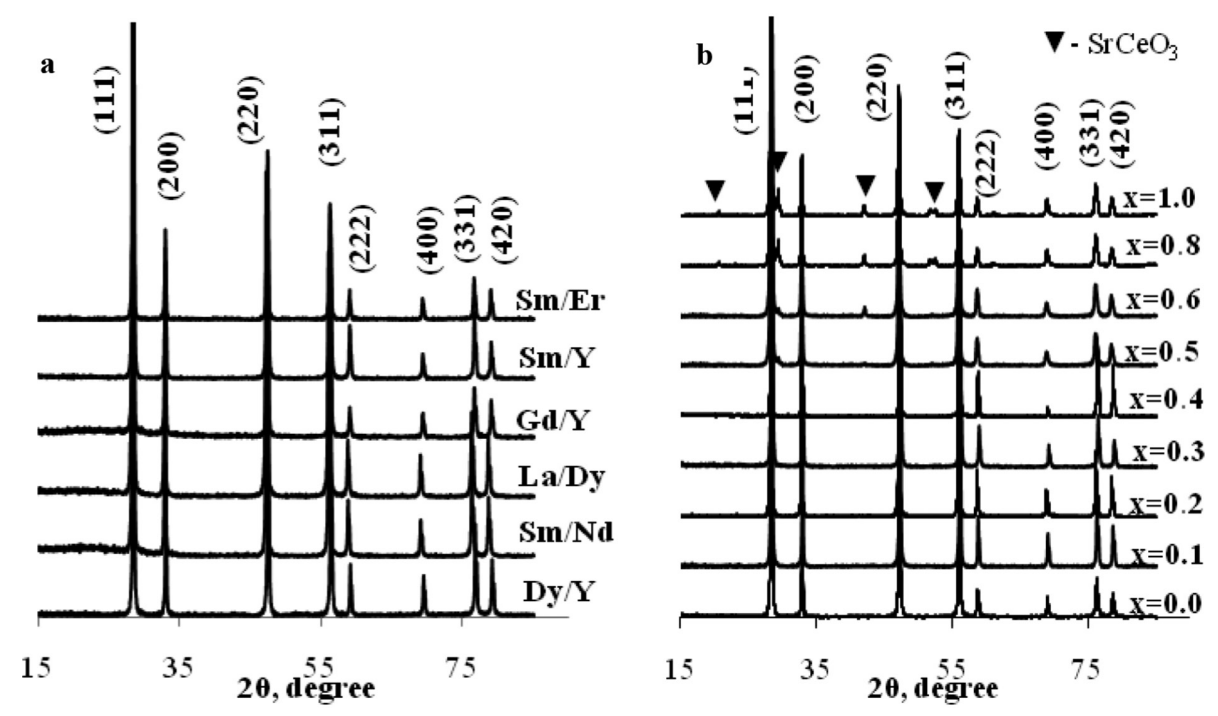

Figure 3: XRD patterns: (a) $\mathrm{Ce}_{0.8}\left(\mathrm{Ln}_{0.5} \mathrm{Ln}_{0.5}^{\prime}\right)_{0.2} \mathrm{O}_{2-\delta}$ and (b) $\mathrm{Ce}_{0.8}\left(\mathrm{Sm}_{1-\mathrm{x}} \mathrm{Sr}_{\mathrm{x}}\right)_{0.2} \mathrm{O}_{2-\delta}$ samples.

hours did not significantly alter the picture. The dilatometric investigation of sintering kinetics showed that the optimal sintering temperatures for a sample preparation with a relative density of no $<95 \%$ were 1400,1500 and $1600^{\circ} \mathrm{C}$ for Laser, Chem and Solid powders, respectively.

\subsection{Electrical properties in air}

Throughout the entire concentration range for two-component systems, the maximum level of conductivity was found when using as a dopant the cations with a large ionic radius such as $\mathrm{Nd}^{3+}$ and $\mathrm{La}^{3+}$ (Table 1). Co-doping with $\mathrm{Y}^{3+}$ leads to a significant decrease in conductivity for both $\mathrm{CeO}_{2}$-based solid solutions doped with $\mathrm{Sm}^{3+}$ and $\mathrm{Gd}^{3+}$. The activation energy for all compositions depends strongly on the dopant concentration at high temperatures and it generally decreases with an increase in the amount of vacancies. In the low-temperature range, the activation energy depends on the concentration to a lesser degree. It is known that in the case of single-doping the $\mathrm{E}_{\mathrm{a}}$ of total conductivity of $\mathrm{CeO}_{2}$-based solid solutions below the critical temperature of $600 \pm 50^{\circ} \mathrm{C}$ [6] increases, which can be explained by ordering of

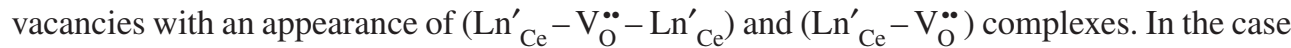
of double-doping, the $\mathrm{E}_{\mathrm{a}}$ tends to decrease with a decrease in temperature (except for high concentrations of dopants with big radii), which may be evidence of a reduction in associative processes as was discussed in [18].

Adding the proper amount of $\mathrm{Ca}^{2+}$ and $\mathrm{Sr}^{2+}(2-4$ mol. \%) significantly increases the total conductivity of the samples (Table 2). The same results were found for $\mathrm{Ce}_{0.8}\left(\mathrm{Sm}_{1-\mathrm{x}-\mathrm{y}}\right.$ $\left.\mathrm{Ba}_{\mathrm{y}} \mathrm{M}_{\mathrm{x}}\right)_{0.2} \mathrm{O}_{2-\delta}(\mathrm{M}=\mathrm{Ca}, \mathrm{Sr} ; \mathrm{x}=0,0.15,0.20 ; \mathrm{y}=0.05,0.1)$. Impedance spectroscopy measurements have confirmed that the addition of alkaline earth elements increases the grain boundary conductivity of samples [19]. It should be noted that the conductivity of the samples with $\mathrm{Sr}^{2+}$ is higher due to the lower binding energy of $\mathrm{Sr}-\mathrm{O}(33.4 \mathrm{eV})$ compared with $\mathrm{Ca}-\mathrm{O}(35.44 \mathrm{eV})[20]$. The binding energy of $\mathrm{Ba}-\mathrm{O}$ is minimal among the alkaline earth elements $(31.44 \mathrm{eV})$, but due to the fact that the effective radius of $\mathrm{Ba}^{2+}$ is $0.142 \mathrm{~nm}$, and its solubility in the fluorite lattice is $<2 \mathrm{~mol} \%$, the number of single-phase solid solutions on the base of $\mathrm{BaO}$ is limited. Nevertheless, it was found that the samples with $\mathrm{Ba}^{2+}$ had the lowest 
Table 1: Cell parameters, total conductivity and activation energy of $\mathrm{Ce}_{1 \mathrm{x}}\left(\operatorname{Ln}_{0.5} \operatorname{Ln}_{0.5}^{\prime}\right)_{\mathrm{x}} \mathrm{O}_{2-\delta}$ samples.

\begin{tabular}{|c|c|c|c|c|c|}
\hline Sample content & $\mathrm{a}(\AA)$ & $\begin{array}{c}\sigma \times 10^{3} \\
(\mathrm{~S} / \mathrm{cm}) \\
750^{\circ} \mathrm{C}\end{array}$ & $\begin{array}{c}\sigma \times 10^{3} \\
(\mathrm{~S} / \mathrm{cm}) \\
600^{\circ} \mathrm{C}\end{array}$ & $\begin{array}{c}\mathrm{Ea}(\mathrm{eV}) \\
\left(600-900^{\circ} \mathrm{C}\right)\end{array}$ & $\begin{array}{c}\mathrm{Ea}(\mathrm{eV}) \\
\left(350-600^{\circ} \mathrm{C}\right)\end{array}$ \\
\hline $\mathrm{Ce}_{0.80}\left(\mathrm{Y}_{0.5} \mathrm{Dy}_{0.5}\right)_{0.20} \mathrm{O}_{2-\delta}$ & 5.4135 & 4.79 & 0.68 & 1.21 & 1.01 \\
\hline $\mathrm{Ce}_{0.80}\left(\mathrm{Sm}_{0.5} \mathrm{Er}_{0.5}\right)_{0.15} \mathrm{O}_{2-\delta}$ & 5.4162 & 7.31 & 0.83 & 1.25 & 0.95 \\
\hline $\mathrm{Ce}_{0.80}\left(\mathrm{Sm}_{0.5} \mathrm{Er}_{0.5}\right)_{0.20} \mathrm{O}_{2-\delta}$ & 5.4162 & 18.72 & 2.81 & 1.11 & 0.89 \\
\hline $\mathrm{Ce}_{0.90}\left(\mathrm{Sm}_{0.5} \mathrm{Nd}_{0.5}\right)_{0.10} \mathrm{O}_{2-\delta}$ & 5.4293 & 9.53 & 0.81 & 1.32 & 1.12 \\
\hline $\mathrm{Ce}_{0.85}\left(\mathrm{Sm}_{0.5} \mathrm{Nd}_{0.5}\right)_{0.15} \mathrm{O}_{2 \delta}$ & 5.4360 & 21.99 & 4.18 & 0.93 & 0.94 \\
\hline $\mathrm{Ce}_{0.80}\left(\mathrm{Sm}_{0.5} \mathrm{Nd}_{0.5}\right)_{0.20} \mathrm{O}_{2-\delta}$ & 5.4377 & 37.18 & 8.98 & 0.80 & 0.86 \\
\hline $\mathrm{Ce}_{0.90}\left(\mathrm{Gd}_{0.5} \mathrm{Y}_{0.5}\right)_{0.10} \mathrm{O}_{2-\delta}$ & 5.4167 & 3.59 & 0.29 & 1.41 & 1.19 \\
\hline $\mathrm{Ce}_{0.85}\left(\mathrm{Gd}_{0.5} \mathrm{Y}_{0.5}\right)_{0.15} \mathrm{O}_{2-\delta}$ & 5.4182 & 6.68 & 0.81 & 1.20 & 1.08 \\
\hline $\mathrm{Ce}_{0.80}\left(\mathrm{Gd}_{0.5} \mathrm{Y}_{0.5}\right)_{0.20} \mathrm{O}_{2-\delta}$ & 5.4178 & 16.35 & 2.34 & 1.09 & 1.00 \\
\hline $\mathrm{Ce}_{0.90}\left(\mathrm{La}_{0.5} \mathrm{Dy}_{0.5}\right)_{0.10} \mathrm{O}_{2-\delta}$ & 5.4275 & 8.44 & 1.28 & 1.14 & 0.76 \\
\hline $\mathrm{Ce}_{0.85}\left(\mathrm{La}_{0.5} \mathrm{Dy}_{0.5}\right)_{0.15} \mathrm{O}_{2-\delta}$ & 5.4351 & 29.85 & 5.19 & 0.96 & 0.97 \\
\hline $\mathrm{Ce}_{0.80}\left(\mathrm{La}_{0.5} \mathrm{Dy}_{0.5}\right)_{0.2} \mathrm{O}_{2-\delta}$ & 5.4404 & 38.28 & 8.67 & 0.83 & 0.86 \\
\hline $\mathrm{Ce}_{0.90}\left(\mathrm{Sm}_{0.5} \mathrm{Y}_{0.5}\right)_{0.10} \mathrm{O}_{2-\delta}$ & 5.4199 & 5.44 & 0.62 & 1.29 & 1.12 \\
\hline $\mathrm{Ce}_{0.85}\left(\mathrm{Sm}_{0.5} \mathrm{Y}_{0.5}\right)_{0.15} \mathrm{O}_{2-\delta}$ & 5.4216 & 7.12 & 0.90 & 1.21 & 1.01 \\
\hline $\mathrm{Ce}_{0.80}\left(\mathrm{Sm}_{0.5} \mathrm{Y}_{0.5}\right)_{0.20} \mathrm{O}_{2-\delta}$ & 5.4235 & 13.63 & 1.95 & 1.10 & 0.96 \\
\hline
\end{tabular}

Table 2: Cell parameters, total conductivity and energy of activation of $\mathrm{Ce}_{0.8}\left(\mathrm{Sm}_{1 \mathrm{x}} \mathrm{M}_{\mathrm{x}}\right)_{0.2} \mathrm{O}_{2-\delta}$ and $\mathrm{Ce}_{0.8}\left(\mathrm{Sm}_{1 \mathrm{xy}} \mathrm{M}_{\mathrm{x}} \mathrm{M}_{\mathrm{y}}^{\prime}\right)_{0.2} \mathrm{O}_{2-\delta}$ samples.

\begin{tabular}{lrrrrr}
\hline & & $\begin{array}{c}\sigma \times 10^{3} \\
(\mathrm{~S} / \mathrm{cm}),\end{array}$ & $\begin{array}{c}\sigma \times 10^{3} \\
(\mathrm{~S} / \mathrm{cm}),\end{array}$ & $\begin{array}{c}\mathrm{Ea}(\mathrm{eV}) \\
\left(600-900^{\circ} \mathrm{C}\right)\end{array}$ & $\begin{array}{c}\mathrm{Ea}(\mathrm{eV}) \\
\left(350-600^{\circ} \mathrm{C}\right)\end{array}$ \\
Sample content & $\mathrm{A}(\AA)$ & $750^{\circ} \mathrm{C}$ & $600^{\circ} \mathrm{C}$ & 0.76 & 0.88 \\
$\mathrm{Ce}_{0.8} \mathrm{Sm}_{0.2} \mathrm{O}_{2-\delta}$ & 5.4349 & 50.23 & 12.56 & 0.76 & 0.79 \\
$\mathrm{Ce}_{0.8}\left(\mathrm{Sm}_{0.9} \mathrm{Ca}_{0.1}\right)_{0.2} \mathrm{O}_{2-\delta}$ & 5.4346 & 43.18 & 11.54 & 0.82 & 0.80 \\
$\mathrm{Ce}_{0.8}\left(\mathrm{Sm}_{0.8} \mathrm{Ca}_{0.2}\right)_{0.2} \mathrm{O}_{2-\delta}$ & 5.4339 & 57.28 & 13.71 & 0.87 & 0.80 \\
$\mathrm{Ce}_{0.8}\left(\mathrm{Sm}_{0.7} \mathrm{Ca}_{0.3}\right)_{0.2} \mathrm{O}_{2-\delta}$ & 5.4325 & 55.40 & 12.99 & 0.93 & 0.89 \\
$\mathrm{Ce}_{0.8}\left(\mathrm{Sm}_{0.6} \mathrm{Ca}_{0.4}\right)_{0.2} \mathrm{O}_{2-\delta}$ & 5.4294 & 53.60 & 11.75 & 1.02 & 0.82 \\
$\mathrm{Ce}_{0.8}\left(\mathrm{Sm}_{0.5} \mathrm{Ca}_{0.5}\right)_{0.2} \mathrm{O}_{2-\delta}$ & 5.4282 & 43.75 & 9.59 & 0.85 & 0.89 \\
$\mathrm{Ce}_{0.8}\left(\mathrm{Sm}_{0.4} \mathrm{Ca}_{0.6}\right)_{0.2} \mathrm{O}_{2-\delta}$ & 5.4260 & 47.01 & 9.12 & 1.02 & 0.78 \\
$\mathrm{Ce}_{0.8}\left(\mathrm{Sm}_{0.9} \mathrm{Sr}_{0.1}\right)_{0.2} \mathrm{O}_{2-\delta}$ & 5.4390 & 63.21 & 15.16 & 0.82 & 0.79 \\
$\mathrm{Ce}_{0.8}\left(\mathrm{Sm}_{0.8} \mathrm{Sr}_{0.2}\right)_{0.2} \mathrm{O}_{2-\delta}$ & 5.4451 & 59.30 & 14.79 & 0.87 & 0.82 \\
$\mathrm{Ce}_{0.8}\left(\mathrm{Sm}_{0.7} \mathrm{Sr}_{0.3}\right)_{0.2} \mathrm{O}_{2-\delta}$ & 5.4492 & 55.00 & 12.40 & 0.84 & 0.76 \\
$\mathrm{Ce}_{0.8}\left(\mathrm{Sm}_{0.6} \mathrm{Sr}_{0.4}\right)_{0.2} \mathrm{O}_{2-\delta}$ & 5.4524 & 36.34 & 7.00 & 0.77 & 0.81 \\
$\mathrm{Ce}_{0.8}\left(\mathrm{Sm}_{0.9} \mathrm{Ba}_{0.1}\right)_{0.2} \mathrm{O}_{2-\delta}$ & 5.4339 & 53.16 & 15.17 & 0.79 & 0.76 \\
$\mathrm{Ce}_{0.8}\left(\mathrm{Sm}_{0.8} \mathrm{Sr}_{0.15} \mathrm{Ba}_{0.05}\right)_{0.2} \mathrm{O}_{2-\delta}$ & 5.4383 & 59.46 & 14.91 & 0.88 & 0.80 \\
$\mathrm{Ce}_{0.8}\left(\mathrm{Sm}_{0.75} \mathrm{Sr}_{0.2} \mathrm{Ba}_{0.05}\right)_{0.2} \mathrm{O}_{2-\delta}$ & 5.4407 & 62.51 & 16.11 & 0.81 & \\
$\mathrm{Ce}_{0.8}\left(\mathrm{Sm}_{0.8} \mathrm{Ca}_{0.15} \mathrm{Ba}_{0.05}\right)_{0.2} \mathrm{O}_{2-\delta}$ & 5.4335 & 34.62 & 7.95 & 0.88 & \\
\hline
\end{tabular}


activation energy for total conductivity. The highest value of total conductivity of $63.21 \times 10^{3}$ $\mathrm{S} / \mathrm{cm}$ at $750^{\circ} \mathrm{C}$ was attributed to $\mathrm{Ce}_{0.8}\left(\mathrm{Sm}_{0.8} \mathrm{Sr}_{0.1}\right)_{0.2} \mathrm{O}_{2-\delta}$.

\subsection{Electrolytic properties}

It is well known that the rate of electrochemical reactions in SOFCs is determined by the driving forces of the processes, which in turn are determined by the difference between the partial pressures of oxygen within the anode and cathode channels. The greater this difference, the higher is the power output of the electrochemical cell. Usually, with the cathode, channel oxygen partial pressure is selected in the range $10^{3}$ to $0.21 \mathrm{~atm}$. Problems arise under reducing conditions (anode channel) since, at the partial pressure of oxygen below $10^{15} \mathrm{~atm}$, ceria systems are characterized by the appearance of electronic conductivity due to the partial reduction of $\mathrm{Ce}^{4+} \rightarrow \mathrm{Ce}^{3+}$. The level of electronic conductivity of solid solutions based on $\mathrm{CeO}_{2}$ at low $\mathrm{pO}_{2}$ is determined by the dopant's radius and its concentration and temperature. The dependence of total conductivity on $\mathrm{pO}_{2}$ was investigated at $750^{\circ} \mathrm{C}$. To describe the electrolytic properties of solid electrolytes, the notation of the electrolytic domain boundary - critical oxygen partial pressure $\mathrm{pO}_{2}{ }^{*}$ at which the values of the electronic and ionic components of conductivity are equal, was used. Among $\mathrm{Ce}_{1-\mathrm{x}}\left(\operatorname{Ln}_{0.5} \operatorname{Ln}_{0.5}^{\prime}\right)_{\mathrm{x}} \mathrm{O}_{2-\delta}$ systems, the lowest values of $\mathrm{pO}_{2}{ }^{*}$ equal to $1.16 \times 10^{-18} \mathrm{~atm}$ was found for $\mathrm{Ce}_{0.8} \mathrm{Nd}_{0.1} \mathrm{Sm}_{0.1} \mathrm{O}_{2-\delta}$. For compositions $\mathrm{Ce}_{0.8}\left(\mathrm{Sm}_{1-\mathrm{x}} \mathrm{M}_{\mathrm{x}}\right)_{0.2} \mathrm{O}_{2-\delta}$, the value of $\mathrm{pO}_{2}{ }^{*}$ increases with $\mathrm{CaO}$ content (with $\mathrm{x}=0,0.2$ and 0.5 are $2.76 \times 10^{-21} ; 5.05 \times 10^{-18}$ and $1.31 \times 10^{-18}$ atm, respectively), while SrO addition lowers the value of $\mathrm{pO}_{2}{ }^{*}$ (with $\mathrm{x}=0.2$ and 0.3 are $3.33 \times 10^{19}$ and $9.98 \times 10^{-23} \mathrm{~atm}$ ). The addition of $\mathrm{BaO}$ also leads to expansion of the electrolytic area of co-doped systems. The lowest value of $2.76 \times 10^{-23}$ atm at $750^{\circ} \mathrm{C}$ was found for $\mathrm{Ce}_{0.8}\left(\mathrm{Sm}_{0.75} \mathrm{Sr}_{0.2} \mathrm{Ba}_{0.05}\right)_{0.2} \mathrm{O}_{2-\delta}$.

In some of the investigations made by the Mori group [12, 21], it was also shown that co-doping with alkali earth elements not only leads to increased electrical conductivity for solid electrolytes based on $\mathrm{CeO}_{2}$, but it also expands their electrolytic areas. The group have developed a strategy to improve the ionic conductivity of materials based on ceria in reducing and oxidizing atmospheres based on the theory of the effective index. According to the first Pauling rule, the crystallographic coordination number of cations is determined by the ratio of the radii of the cations and anions $\left(\mathrm{r}_{\mathrm{cat}} / \mathrm{r}_{\mathrm{an}}\right)$. This number is crucial for the fluorite-type structure. The coordination number of cations in the ideal fluorite structure is equal to 8 and for the formation of a stable structure, the $r_{c a t} / r_{\text {an }}$ should only vary from 0.732 to 1 . It has been shown that a formation enthalpy of dopant cation-oxygen vacancy associations at low temperatures and, respectively, energy activation, $\mathrm{E}_{\mathrm{a}}$, of total conductivity is minimal, when $\mathrm{r}_{\mathrm{cat}} / \mathrm{r}_{\mathrm{an}} \rightarrow 1[22,23]$. The effective index is determined from the ionic radii and the number of oxygen vacancies appearing on doping:

$$
\text { Effective index }=\left(\text { avg } \mathrm{r}_{\text {cat }} / \text { eff } \mathrm{r}_{\mathrm{O}}\right) \times\left(\mathrm{r}_{\mathrm{d}} / \mathrm{r}_{\mathrm{h}}\right),
$$

where avg $r_{\text {cat }}$ is the average ionic radius of cations and eff $r_{O}$ is the effective ionic radius of oxygen, defined as follows:

$$
\text { eff } \mathrm{r}_{\mathrm{O}}=1.4\{(2-\delta) / 2\} \text {, }
$$

where $\delta$ is the level of oxygen non-stoichiometry in the doped ceria, 1.4 is the ionic radius of oxygen in sixfold coordination, $r_{d}$ is the average ionic radius of the dopant and $r_{h}$ is the ionic radius of $\mathrm{Ce}^{4+}$ (host cation). When both avg $\mathrm{r}_{\text {cat }} /$ eff $\mathrm{r}_{\mathrm{O}}$ and $\mathrm{r}_{\mathrm{d}} / \mathrm{r}_{\mathrm{h}}$ and, respectively, the value of the effective index approach unity, the distortion in the fluorite structure decreases and binding energy between the cation and anion in the fluorite structure becomes minimal, which facilities ionic transport. It has been shown experimentally utilizing a transmission electron 
Table 3: Correlation between effective index and electrical and electrolytic properties of $\mathrm{CeO}_{2}$-based solid-state electrolytes.

\begin{tabular}{lccc}
\hline Sample content & $\begin{array}{c}\sigma \times 10^{3}(\mathrm{~S} / \mathrm{cm}), \\
750^{\circ} \mathrm{C}\end{array}$ & $\begin{array}{c}\mathrm{pO}_{2}{ }^{*}(\mathrm{~atm}), \\
750 \mathrm{C}\end{array}$ & Eff. index \\
\hline $\mathrm{Ce}_{0.8} \mathrm{Sm}_{0.2} \mathrm{O}_{2-\delta}$ & 50.23 & $2.76 \times 10^{-21}$ & 0.830 \\
$\mathrm{Ce}_{0.8} \mathrm{Nd}_{0.2} \mathrm{O}_{2-\delta}$ & 55.86 & $7.50 \times 10^{-20}$ & 0.858 \\
$\mathrm{Ce}_{0.8} \mathrm{La}_{0.2} \mathrm{O}_{2-\delta}$ & 36.00 & $2.20 \times 10^{-18}$ & 0.906 \\
$\mathrm{Ce}_{0.8}\left(\mathrm{Sm}_{0.7} \mathrm{Ca}_{0.3}\right)_{0.2} \mathrm{O}_{2-\delta}$ & 55.40 & $1.31 \times 10^{-18}$ & 0.859 \\
$\mathrm{Ce}_{0.8}\left(\mathrm{Sm}_{0.8} \mathrm{Sr}_{0.2}\right)_{0.2} \mathrm{O}_{2-\delta}$ & 59.30 & $3.33 \times 10^{-19}$ & 0.873 \\
$\mathrm{Ce}_{0.8}\left(\mathrm{Sm}_{0.7} \mathrm{Sr}_{0.3}\right)_{0.2} \mathrm{O}_{2-\delta}$ & 55.00 & $9.98 \times 10^{-23}$ & 0.895 \\
$\mathrm{Ce}_{0.8}\left(\mathrm{Sm}_{0.5} \mathrm{Y}_{0.5}\right)_{0.2} \mathrm{O}_{2-\delta}$ & 13.63 & $2.20 \times 10^{-16}$ & 0.802 \\
$\mathrm{Ce}_{0.8}\left(\mathrm{La}_{0.5} \mathrm{Dy}_{0.5}\right){ }_{0.2} \mathrm{O}_{2-\delta}$ & 38.28 & $1.21 \times 10^{-17}$ & 0.843 \\
$\mathrm{Ce}_{0.8}\left(\mathrm{Sm}_{0.5} \mathrm{Nd}_{0.5}\right)_{0.2} \mathrm{O}_{2-\delta}$ & 37.18 & $2.40 \times 10^{-18}$ & 0.844 \\
$\mathrm{Ce}_{0.8}\left(\mathrm{Gd}_{0.75} \mathrm{Sr}_{0.2} \mathrm{Ba}_{0.05}\right)_{0.2} \mathrm{O}_{2-\delta}$ & 44.84 & $5.05 \times 10^{-18}$ & 0.876 \\
$\mathrm{Ce}_{0.8}\left(\mathrm{Sm}_{0.75} \mathrm{Sr}_{0.2} \mathrm{Ba}_{0.05}\right)_{0.2} \mathrm{O}_{2-\delta}$ & 62.51 & $2.76 \times 10^{-23}$ & 0.892 \\
$\mathrm{Ce}_{0.825}\left(\mathrm{La}_{0.75} \mathrm{Sr}_{0.2} \mathrm{Ba}_{0.05}\right)_{0.175} \mathrm{O}_{2-\delta}$ & 60.73 & $6.58 \times 10^{-24}$ & 0.951 \\
\hline
\end{tabular}

spectroscopy that for solid solutions with a high effective index, the ordering of oxygen vacancies is reduced [23]. Our calculations and experimental results (Table 3) and the data presented by Mori et al. [23] have revealed that in many cases, the total conductivity of ceriabased solutions increases and the electrolytic domain also broadens with increasing effective index. Nevertheless, not only should structural parameters be considered when selecting the dopant strategy but also the association energy of the dopant with oxygen vacancies.

\subsection{Electrochemical performance}

The electrochemical characteristics of the $\mathrm{Ce}_{0.8}\left(\mathrm{Sm}_{0.75} \mathrm{Sr}_{0.2} \mathrm{Ba}_{0.05}\right)_{0.2} \mathrm{O}_{2-\delta}(\mathrm{CSSBO})$ and $\mathrm{Ce}_{0.8} \mathrm{Sm}_{0.2} \mathrm{O}_{1.9}$ (CSO) electrolyte supported SOFCs were measured using the experimental set presented in Fig. 1b. To prepare electrolyte support, the powders synthesized by solid-state reaction (Solid), laser evaporation (Laser) and glycine-nitrate (Chem) methods were compacted by the magnetic pulse technique into disks $30 \mathrm{~mm}$ in diameter, sintered at $1500-1600^{\circ} \mathrm{C}$ and polished to $0.8 \mathrm{~mm}$ in thickness. A Pt-based anode and cathode was painted on the disks' opposite sides, sintered at $1000^{\circ} \mathrm{C}, 1 \mathrm{~h}$ and activated (see Section 2). It was found that the electrochemical properties of $\mathrm{Ce}_{0.8} \mathrm{Sm}_{0.2} \mathrm{O}_{1.9}$ were strongly influenced by the method of preparation, and samples made from micro-sized powders had both superior density and electrical properties (Fig. 4). The specific powders of the single electrochemical cells based on Solid, Chem and Laser electrolyte powders were 80,120 and $130 \mathrm{~mW} / \mathrm{cm}^{2}$ at $750^{\circ} \mathrm{C}$ (with open-circuit voltage, $\mathrm{OCV}$ ) values $0.75,0.79$ and $0.80 \mathrm{~V}$, respectively). It was also found that co-doping by $\mathrm{Sr}^{2+}$ and $\mathrm{Ba}^{2+}$ significantly improved not only the electrical and electrolytic properties but also the electrochemical properties of the $\mathrm{CeO}_{2}-\mathrm{Sm}_{2} \mathrm{O}_{3}$ electrolyte. The specific power of the single SOFC based on the $\left(\mathrm{Sm}_{0.75} \mathrm{Sr}_{0.2} \mathrm{Ba}_{0.05}\right)_{0.2} \mathrm{Ce}_{0.8} \mathrm{O}_{2-\delta}$ electrolyte prepared by the laser evaporation method reached $450 \mathrm{~mW} / \mathrm{cm}^{2}$ at $750^{\circ} \mathrm{C}$ (with $\mathrm{OCV}$ values of $0.95 \mathrm{~V}$ ), which is more than three times higher than that of $\mathrm{Ce}_{0.8} \mathrm{Sm}_{0.2} \mathrm{O}_{1.9}$ prepared by the same method and approximately nine times higher compared with the traditional $8 \%$ $\mathrm{Y}_{2} \mathrm{O}_{3}-\mathrm{ZrO}_{2}$ electrolyte (the samples were made at the Chepetsk ceramic plant). 


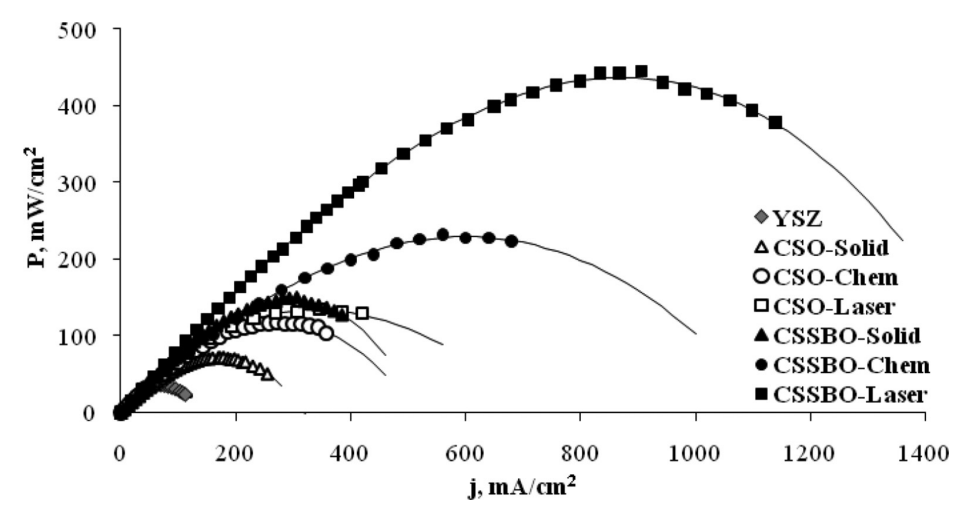

Figure 4: Electrochemical performance (specific power) of single SOFCs with $\mathrm{Ce}_{0.8} \mathrm{Sm}_{0.2}$ $\mathrm{O}_{1.9}$ and $\left(\mathrm{Sm}_{0.75} \mathrm{Sr}_{0.2} \mathrm{Ba}_{0.05}\right)_{0.2} \mathrm{Ce}_{0.8} \mathrm{O}_{2-\delta}$ supported electrolyte $(0.8 \mathrm{~mm})$ made by different methods (measured at $750^{\circ} \mathrm{C}$ with $\mathrm{H}_{2}+5 \% \mathrm{H}_{2} \mathrm{O}$ as a fuel and air as an oxidizer).

\section{ELECTROCHEMICAL APPLICATIONS FOR DEVELOPED MULTICOMPONENT ELECTROLYTES}

\subsection{Potentiometric sensor}

A tube cell on the base of $\left(\mathrm{Sm}_{0.75} \mathrm{Sr}_{0.2} \mathrm{Ba}_{0.05}\right)_{0.2} \mathrm{Ce}_{0.8} \mathrm{O}_{2-\delta}$ as a model of a potentiometric sensor is presented in [24]. It should be noted that tube elements can be manufactured by using both the calendering and the aqueous slurry casting methods. A silver reference electrode was placed within the tube under an air flow (Fig. 5). The studied electrodes were applied to the outer surface of the tube and were then blown over by the reference gas mixtures of $\mathrm{N}_{2}+\mathrm{O}_{2}$ at the rate of $100 \mathrm{ml} / \mathrm{min}$. Platinum wires were used as current collectors. Silver electrodes were sintered at $750^{\circ} \mathrm{C}$ for $1 \mathrm{~h}$. Electrodes of perovskite structure $\mathrm{LaNi}_{0.6} \mathrm{Co}_{0.4} \mathrm{O}_{3-\delta}, \mathrm{La}_{0.6} \mathrm{Sr}_{0.4} \mathrm{CoO}_{3-\delta}$ +1 wt. $\% \mathrm{Co}_{2} \mathrm{O}_{3}, \mathrm{La}_{0.7} \mathrm{Sr}_{0.3} \mathrm{CoO}_{3-\delta}+1$ wt. $\% \mathrm{CuO}$ were sintered at temperatures of $1200^{\circ} \mathrm{C}$, $1150^{\circ} \mathrm{C}$ and $1050^{\circ} \mathrm{C}$, respectively. Measurements of voltage levels between the studied electrodes and the reference electrode were carried out using an E-24 module connected to the computer with the accuracy of measurements $0.01 \mathrm{mV}$. The cell temperature was maintained with an accuracy rating of $\pm 1^{\circ} \mathrm{C}$ using a TPM-10 controller. To determine the rate of the electrode potential response with a change in the oxygen content in the gas mixture above the electrode investigated that the time dependences of the electrode potential were measured under a regime of rapid (over a period of $\sim 1 \mathrm{~s}$ ) change from a mixture containing $1.25 \mathrm{vol} \%$ of $\mathrm{O}_{2}$ to a mixture with a concentration of $4.15 \mathrm{vol}$. \% of $\mathrm{O}_{2}$ with further exposure for $22 \mathrm{~s}$ and reverse replacement of gas mixtures. The measurement frequency was $100 \mathrm{~Hz}$ with an average of 10 measurements for each experimental point. The lowest response time of $2.4 \mathrm{~s}$ at $650^{\circ} \mathrm{C}$ corresponds to the electrode with the composition of $\mathrm{La}_{0.6} \mathrm{Sr}_{0.4} \mathrm{CoO}_{3-\delta}+1 \mathrm{wt} . \% \mathrm{Co}_{2} \mathrm{O}_{3}$. Minimal temperature, at which the deviation of the electrode potential from the equilibrium value is no more than $1 \mathrm{mV}$, was found to be $480^{\circ} \mathrm{C}$ for this electrode composition and $420^{\circ} \mathrm{C}$ for $\mathrm{La}_{0.7} \mathrm{Sr}_{0.3} \mathrm{CoO}_{3-\delta}+1$ wt. $\% \mathrm{CuO}$ electrode in a gas mixture with 1.25 vol. $\% \mathrm{O}_{2}$.

4.2 Hydrogen production by MIEC composite membranes on the base of a multi-component ceria electrolyte

The new composite materials $(1-\mathrm{x}) \mathrm{SrTi}_{0.5} \mathrm{Fe}_{0.5} \mathrm{O}_{3-\delta}-\mathrm{xCe}_{0.8}\left(\mathrm{Sm}_{0.8} \mathrm{Sr}_{0.2}\right)_{0.2} \mathrm{O}_{2-\delta}(\mathrm{x}=0,0.25$, $0.5,0.75$ and 1$)$ were prepared by the solid-state reaction method [25]. The system displayed 


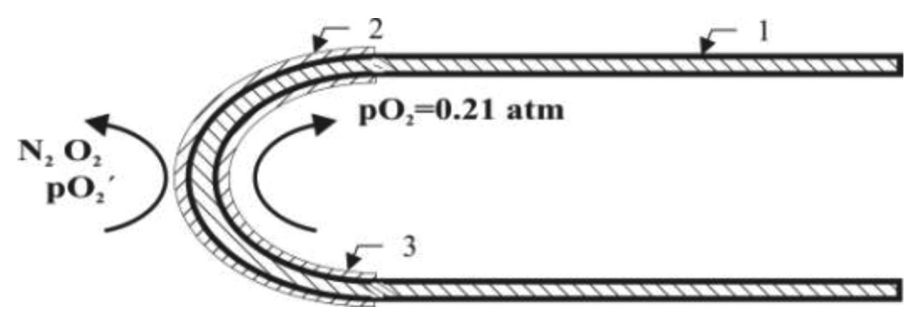

Figure 5: Potentiometric cell on the base of $\left(\mathrm{Sm}_{0.75} \mathrm{Sr}_{0.2} \mathrm{Ba}_{0.05}\right)_{0.2} \mathrm{Ce}_{0.8} \mathrm{O}_{2-\delta}: 1$ - electrolyte tube, 2 - electrode under investigation, 3 - reference electrode (Ag).

high structural stability after sintering $\left(1350-1550^{\circ} \mathrm{C}, 5 \mathrm{~h}\right)$ and in long-term testing in a hostile atmosphere $\left(900^{\circ} \mathrm{C}, 600 \mathrm{~h}, \mathrm{pO}_{2}=1 \times 10^{-18} \mathrm{~atm}\right)$. No secondary phases were observed after the treatment. It was found that the composite materials were characterized by the retention of good mechanical properties that are attributable to their microhardness increasing in comparison with $\mathrm{SrTi}_{0.5} \mathrm{Fe}_{0.5} \mathrm{O}_{3-\delta}$ from 940 to $1100-1130 \mathrm{~kg} / \mathrm{mm}^{2}$ and an improvement in the intergranular contact relative to $\mathrm{Ce}_{0.8}\left(\mathrm{Sm}_{0.8} \mathrm{Sr}_{0.2}\right)_{0.2} \mathrm{O}_{2-\delta}$. With an increase in the fluorite content $(\mathrm{x}=0,0.25,0.5,0.75$ and 1$)$, a decrease in p-type electronic (hole) conductivity was detected in air $\left(1.061,1.025,0.574,0.157\right.$ and $0.147 \mathrm{~S} / \mathrm{cm}$ at $900^{\circ} \mathrm{C}$, respectively), also widening of the ionic conductivity area and an increase in ionic conductivity $(0.062,0.068$, $0.077,0.111$ and $0.157 \mathrm{~S} / \mathrm{cm}$ at $900^{\circ} \mathrm{CC}$ ) over the range of intermediate $\mathrm{pO}_{2}$ values and an increase in n-type electronic conductivity at low $\mathrm{pO}_{2}(0.227,0.418,0.703,1.009$ and $0.157 \mathrm{~S} /$ $\mathrm{cm}$ at $\left.900^{\circ} \mathrm{C}, \mathrm{pO}_{2}=1 \times 10^{-18} \mathrm{~atm}\right)$. The composite material of $0.5 \mathrm{SrTi}_{0.5} \mathrm{Fe}_{0.5} \mathrm{O}_{3-\delta}-0.5$ $\mathrm{Ce}_{0.8} \mathrm{x}\left(\mathrm{Sm}_{0.8} \mathrm{Sr}_{0.2}\right)_{0.2} \mathrm{O}_{2-\delta}$ has good mechanical and phase stability under actual operating conditions and is suitable for producing hydrogen. It can be successfully applied to devices for electrochemical water dissociation and hydrogen production [26, 27].

\section{CONCLUSIONS}

The investigation of multi-component systems $\mathrm{Ce}_{1 \mathrm{x}}\left(\operatorname{Ln}_{0.5} \mathrm{Ln}_{0.5}^{\prime}\right)_{\mathrm{x}} \mathrm{O}_{2-\delta}(\mathrm{x}=0-0.20 ; \mathrm{Ln}=$ Sm, La, Gd and $\left.\mathrm{Ln}^{\prime}=\mathrm{Dy}, \mathrm{Nd}, \mathrm{Y}\right), \mathrm{Ce}_{0.8}\left(\mathrm{Sm}_{1 \mathrm{x}} \mathrm{M}_{\mathrm{x}}\right)_{0.2} \mathrm{O}_{2-\delta}$ and $\mathrm{Ce}_{0.8}\left(\mathrm{Sm}_{1 \mathrm{xy}} \mathrm{Ba}_{\mathrm{y}} \mathrm{M}_{\mathrm{x}}\right)_{0.2} \mathrm{O}_{2-\delta}$ $(\mathrm{M}=\mathrm{Ca}, \mathrm{Sr})$ showed that increased conductivity in comparison with single-doped solid solutions is observed only with the addition of alkaline earth elements. The highest value for total conductivity in air was found to be equal to 62.5 and $63.2 \times 10^{3} \mathrm{~S} / \mathrm{cm}$ at $750^{\circ} \mathrm{C}$ for $\mathrm{Ce}_{0.8}\left(\mathrm{Sm}_{0.75} \mathrm{Sr}_{0.20} \mathrm{Ba}_{0.05}\right)_{0.2} \mathrm{O}_{2-\delta}$ and $\mathrm{Ce}_{0.8}\left(\mathrm{Sm}_{0.8} \mathrm{Sr}_{0.1}\right)_{0.2} \mathrm{O}_{2-\delta}$ electrolytes. It was shown that co-doping with $\mathrm{SrO}$ and $\mathrm{BaO}$ not only leads to increased electrical conductivity for solid electrolytes based on $\mathrm{CeO}_{2}$ but also expands their electrolytic area. The lowest value of $2.76 \times 10^{-23}$ atm of the critical oxygen partial pressure was registered for $\mathrm{Ce}_{0.8}\left(\mathrm{Sm}_{0.75}\right.$ $\left.\mathrm{Sr}_{0.2} \mathrm{Ba}_{0.05}\right)_{0.2} \mathrm{O}_{2-\delta}$ at $750^{\circ} \mathrm{C}$. It was discovered that the electrochemical properties of electrolytes are strongly affected both by their chemical content and the method of preparation. The best characteristics were found for a single SOFC based on $\left(\mathrm{Sm}_{0.75} \mathrm{Sr}_{0.2} \mathrm{Ba}_{0.05}\right)_{0.2} \mathrm{Ce}_{0.8} \mathrm{O}_{2-\delta}$ electrolyte, prepared by the laser evaporation of the ceramic target method. The specific power for the cell with a supported electrolyte $0.8-\mathrm{mm}$ thick reached $450 \mathrm{~mW} / \mathrm{cm}^{2}$ at $750^{\circ} \mathrm{C}$ (with OCV values of $0.95 \mathrm{~V}$ ), which is three times higher than that for $\mathrm{Ce}_{0.8} \mathrm{Sm}_{0.2} \mathrm{O}_{1.9}$ and nine times that of a traditional YSZ electrolyte. It was demonstrated that multicomponent electrolytes can be used in intermediate temperature electrochemical devices including SOFCs, gas sensors and as a component of MIEC membranes for hydrogen and synthesis gas production. The future investigations will be concentrated on the development of electrode-supported cells with a thin film $\mathrm{CeO}_{2}$-based electrolyte prepared by calendering, electrophoretic deposition and ceramic methods. 


\section{ACKNOWLEDGEMENTS}

The present work was financially supported by Russian Foundation for Basic Research and Government of Sverdlovsk region, grant no. 13-03-96098.

\section{REFERENCES}

[1] Irvine, J.T.S. \& Connor, P. (eds), Solid Oxide Fuel Cells: Facts and Figure, Green Energy and Technology, Springer-Verlag: London, pp. 1-231, 2013. http://dx.doi.org/10.1007/978-1-4471-4456-4

[2] European Commission's Communication, Energy 2020 - A Strategy for Competitive, Sustainable and Secure Energy, Brussels, 2010. www.inforse.org/europe/eu_EE_energystrategy2020.htm.

[3] Korovin, N.V., Fuel Cells and Electrochemical Energy Systems, MEI: Moscow pp. 1-280, 2005.

[4] Fuel Cell Annual Review, 4th Energy Wave, 2014, www.4thenergywave.co.uk/wpcontent/plugins/datavisualisation/data/Fuel-Cell-Annual-Review-2013.pdf.

[5] Skolkovo Fund projects in the field of power-efficient technologies, http://esco-ecosys. narod.ru/esco/2013_4/art32.pdf.

[6] Mogensen, M., Sammes, N.M. \& Tompsett, A.G., Physical, chemical and electrochemical properties of pure and doped ceria. Solid State Ionics, 129(1-4), pp. 63-94, 2000. http://dx.doi.org/10.1016/S0167-2738(99)00318-5

[7] Antonucci, V., Antonucci, P.L., Gullo, L., La Rosa, D. \& Siracusano, S., Advanced (electro) ceramics and innovative energy technologies. Journal of European Ceramic Society, 24, pp. 1337-1342, 2004. http://dx.doi.org/10.1016/S0955-2219(03)00560-0

[8] Ilhan, Z., Ansar, A. \& Soysal, D., Recent progress in intermediate temperature SOFCs (ITSOFCs) Development at DLR, Institute of Electrochemistry and Energy Systems. Proceedings of the International Workshop Advances and Innovations in SOFCs, Katarino, Bulgaria, pp. 30-36, 2011.

[9] Nesaraj, A.S., Recent developments in solid oxide fuel cell technologies - a review. Journal of Scientific and Industrial Research, 69, pp. 169-176, 2010.

[10] Kharton, V.V., Yaremchenko, A.A., Naumovich, A.A. \& Marques, F.M.B., Research on the electrochemistry of oxygen ion conductors in the former Soviet Union. III. $\mathrm{HfO}_{2}, \mathrm{CeO}_{2}-$ and $\mathrm{ThO}_{2}$-based oxides. Journal of Solid State Electrochemistry, 4, pp. 243-266, 2000. http://dx.doi.org/10.1007/s100080050202

[11] Maricle, D.L., Swarr, T.E. \& Karavolis, S., Enhanced ceria - a low-temperature SOFC electrolyte. Solid State Ionics, 52(1-3), pp. 173-182, 1992. http://dx.doi.org/10.1016/0167-2738(92)90103-V

[12] Mori, T., Drennan, J., Wang, Y., Li, J.-G. \& Ikegami T., Influence of nano-structure on electrolytic properties in $\mathrm{CeO}_{2}$ based system. Journal of Thermal Analysis and Calorimetry, 70, pp. 309-319, 2002.

http://dx.doi.org/10.1023/A:1021691500201

[13] Pikalova, E.Yu., Bamburov, V.G., Rukavishnikova, I.V., Demin, A.K. \&. Kolchugin, A.A., Development of electrolytes for intermediate temperature solid oxide fuel cells. WIT Transactions on Ecology and the Environment, 190(1), pp. 261-272, 2014. http://dx.doi.org/10.2495/EQ140261

[14] Gorelov, V.P., Zayats, S.V., Ivanov, V.V., Ivin, S.Yu., Kotov, Yu.A., Medvedev, A.I., Moskalenko, N.I., Murzakaev, A.M., Samatov, O.M. \& Khrustov, V.R., Gadolinium- 
doped ceria ceramica with a submicron structure for electrochemical applications. Glass Physics and Chemistry, 31(4), pp. 471-476, 2005.

http://dx.doi.org/10.1007/s10720-005-0085-x

[15] Pikalova, E.Yu., Nikonov, A.V., Zhuravlev, V.D., Bamburov, V.G., Samatov, O.M., Lipilin, A.S., Khrustov, V.R., Nikolaenko, I.V., Plaksin, S.V. \& Molchanova, N.G., Effect of the synthesis technique on the physicochemical properties of $\mathrm{Ce}_{0.8}\left(\mathrm{Sm}_{0.75}\right.$ $\left.\mathrm{Sr}_{0.2} \mathrm{Ba}_{0.05}\right)_{0.2} \mathrm{O}_{2-\delta}$. Inorganic Materials, 47(4), pp. 396-401, 2011.

http://dx.doi.org/10.1134/S0020168511040170

[16] Ivanov, V.V., Paranin S.N. \& Vikhrev A.N., Method of pulsed pressing of solid powder materials and the setup for its implementation, Patent RU 2083328, 1996.

[17] Yaroslavtsev, I.Yu., Kuzin, B.L., Bronin, D.I., Vdovin, G.K. \& Bogdanovich, N.M., Cathodes based on (La,Sr) $\mathrm{MnO}_{3}$ modified with $\mathrm{PrO}_{2-\mathrm{x}}$. Russian Journal of Elecrochemistry, 45, pp. 875-880, 2009.

http://dx.doi.org/10.1134/S1023193509080060

[18] Sha, X., Lü, Z., Huang, X., Miao, J., Ding, Z., Xin, X. \& Su, W., Study on La and Y co-doped ceria-based electrolyte materials. Journal of Alloys and Compounds, 428, pp. 59-64, 2007.

http://dx.doi.org/10.1016/j.jallcom.2006.03.077

[19] Pikalova, E.Yu, Murashkina, A.A. \& Medvedev, D.A., Structural and electric properties of the $\mathrm{Ce}_{0.8}\left(\mathrm{Sm}_{1-\mathrm{x}} \mathrm{Ca}_{\mathrm{x}}\right)_{0.2} \mathrm{O}_{2-\delta}$ system $(\mathrm{x}=0.0-1.0)$. Russian Journal of Electrochemistry, 47(6), pp. 681-689, 2011.

http://dx.doi.org/10.1134/S1023193511060115

[20] Yeh, T.-H. \& Chou, C.-C., Ionic conductivity investigation in samarium and strontium co-doped ceria system. Physica Scripta, T129, pp. 303-307, 2007. http://dx.doi.org/10.1088/0031-8949/2007/T129/067

[21] Mori, T. \& Yamamura, H., Preparation of an alkali-element or alkali-earth-elementdoped $\mathrm{CeO}_{2}-\mathrm{Sm}_{2} \mathrm{O}_{3}$ system and its operation properties as the electrolyte in planar solid oxide fuel cells. Journal of Materials Synthesis and Processing, 6, pp. 175-179, 1998. http://dx.doi.org/10.1023/A:1022669519414

[22] Kilner, J.A. \& Brook, R.J., Study of oxygen ion conductivity in doped non-stoichiometric oxides. Solid State Ionics, 6(3), pp. 237-252, 1982.

http://dx.doi.org/10.1016/0167-2738(82)90045-5

[23] Mori, T., Drennan, J., Wang, Y., Lee, J.-H., Li, J.-G. \& Ikegami T., Electrolytic properties and nanostructural features in the $\mathrm{La}_{2} \mathrm{O}_{3}-\mathrm{CeO}_{2}$ System. Journal of the Electrochemical Society, 150(6), pp. A665-A673, 2003.

http://dx.doi.org/10.1149/1.1567265

[24] Pikalova, E.Yu., Fadeev, G.I., Kalyakin, A.S., Demin, A.C. \& Somov, S.I., Potentiometric cell with oxygen-conducting solid electrolyte based on ceria. Russian Journal of Electrochemistry, 46(7), pp. 820-826, 2010.

http://dx.doi.org/10.1134/S1023193510070165

[25] Pikalova, E.Yu., Murashkina, A.A., Medvedev, D.A., Pikalov, P.S. \& Plaksin, S.V., Microstructure and electrical properties of the composites based on $\operatorname{SrTi}_{0.5} \mathrm{Fe}_{0.5}$ $\mathrm{O}_{3-\delta}$ andCe $_{0.8}\left(\mathrm{Sm}_{0.8} \mathrm{Sr}_{0.2}\right)_{0.2} \mathrm{O}_{2-\delta}$. Solid State Ionics, 262, pp. 640-644, 2014.

[26] Murashkina, A., Pikalova, E., Medvedev, D., Demin A. \& Tsiakaras P., Hydrogen production aided by new (1-x) $\mathrm{SrTi}_{0.5} \mathrm{Fe}_{0.5} \mathrm{O}_{3-\delta}-\mathrm{xCe}_{0.8}\left(\mathrm{Sm}_{0.8} \mathrm{Sr}_{0.2}\right)_{0.2} \mathrm{O}_{2-\delta}$ (MIEC) composite membranes. International Journal of Hydrogen Energy, 39, pp. 12472-12479, 2014. http://dx.doi.org/10.1016/j.ijhydene.2014.06.068

[27] Pikalova, E., Murashkina, A., Medvedev, D. \& Demin, A., Solid oxide composite material for membranes of electrochemical devices, Patent RU 2510385, 2014. 